\title{
Serological and Molecular Assays for Rapid and Sensitive Detection of Iris yellow spot virus Infection of Bulb and Seed Onion Crops
}

\author{
H. R. Pappu, I. M. Rosales, and K. L. Druffel, Department of Plant Pathology, Washington State University, Pull- \\ man 99164-6430
}

\begin{abstract}
Pappu, H. R., Rosales, I. M., and Druffel, K. L. 2008. Serological and molecular assays for rapid and sensitive detection of Iris yellow spot virus infection of bulb and seed onion crops. Plant Dis. 92:588-594.

Iris yellow spot virus (IYSV) has spread rapidly in the United States and has become an important economic constraint to the production of both bulb and seed onion crops. Symptoms caused by IYSV may be confused with those caused by other fungal and bacterial pathogens and virusspecific, reliable, sensitive, and rapid detection methods would improve the diagnosis. Antiserum was produced to Escherichia coli-expressed nucleocapsid protein of IYSV and an indirect format of the enzyme-linked immunosorbent assay (ELISA) was developed. IYSV could be detected in onion tissue at dilutions of up to 1:1,000. An IYSV-specific primer pair was designed and used in a real-time reverse-transcription polymerase chain reaction (RT-PCR) assay for the rapid detection of IYSV. Compared with standard RT-PCR, real-time RT-PCR was more rapid and sensitive. A commercially available RNA extraction kit and a total nucleic acid extraction method were compared for the quality of the templates obtained for use in real-time RT-PCR and there was no difference in limits of detection. Availability of ELISA- and PCR-based rapid and sensitive detection methods would facilitate accurate virus diagnosis and aid in better understanding of the epidemiology of the disease and in development of management strategies.
\end{abstract}

Additional keywords: Bunyaviridae, Tospovirus

Iris yellow spot virus (IYSV) is an economically important viral pathogen of seed and bulb onion production in the United States (4,6-8). The virus first was reported in the Treasure Valley of southern Idaho in the early 1990s (9) and primarily was confined to seed crops in that area. Since 2000, however, outbreaks of IYSV began to impact both seed and bulb crops in the Treasure Valley area (14). Reports of IYSV on onion in various states and several parts of the world have increased since 2000 (7). Since the review by Gent et al. (7), the increasing incidence of IYSV in bulb and seed crops in southern California's Imperial and Antelope Valleys has been reported (22), and the most recent reports of IYSV were from New York State in the United States (11) and the Burgundy area in France (12).

Corresponding author: H. R. Pappu

E-mail: hrp@wsu.edu

Current address of I. M. Rosales: Instituto de Investigaciones Agropecuarias (INIA) - Centro Regional La Platina, Casilla 439-3, Santiago, Chile.

* The $\boldsymbol{e}$-Xtra logo stands for "electronic extra" and indicates that Figures 1 and 2 are in color in the online edition.

Accepted for publication 13 November 2007.

doi:10.1094/PDIS-92-4-0588

(C) 2008 The American Phytopathological Society
IYSV is one of the three tospoviruses known to occur in the United States (16). A distinct member of the genus Tospovirus, family Bunyaviridae, this virus has a segmented, single-stranded RNA genome $(2,15)$. The large (L) RNA is organized in negative-sense coding for a polymerase, while the medium (M) and small (S) RNAs are ambisense in their genome organization. The M RNA codes for glycoproteins $\left(G_{N}\right.$ and $\left.G_{C}\right)$ and a nonstructural protein, NSm. The S RNA codes for the nucleocapsid $(\mathrm{N})$ and the nonstructural (NSs) proteins. Sequence diversity in the natural populations of IYSV isolates from the United States has been reported $(1,19,20)$. The only confirmed vector of IYSV is onion thrips, Thrips tabaci $(13,18)$, and there is no evidence of virus transmission through seed. Hence, infected plants and viruliferous thrips are the primary sources and means for virus spread.

Management options for IYSV are limited. Though tospoviruses are transmitted by thrips in a circulative and propagative manner $(29,30)$, thrips control practices had limited affect in reducing Tomato spotted wilt virus (TSWV) incidence in row crops (3) unless they were applied early in the season $(24,25)$. At present, avoiding factors that cause plant stress such as drought and nutrition deficiency, managing overlapping crops that are hosts for the virus and onion thrips are recommended for reducing the impact of IYSV in onion $(7,27)$.
One of the prerequisites to develop a management program is the ability to accurately diagnose IYSV infection. IYSV infection often is associated with characteristic diamond-shaped lesions on scapes of infected plants that are of diagnostic value $(5,10,21)$. However, depending on the age of the crop, infection also is known to be associated with less defined symptoms on leaves that could be confused with those caused by fungal or bacterial diseases (9). Additionally, the necrotic areas resulting from IYSV infection could be colonized by secondary invaders such as Stemphylium spp. or Alternaria spp., leading to inaccurate diagnosis. Reliable, rapid, and sensitive detection tests are necessary in such cases for accurate diagnosis. Using Escherichia coli-expressed recombinant N protein of IYSV, antiserum was produced and evaluated for rapid and reliable detection of IYSV in an indirect format of enzyme-linked immunosorbent assay (ELISA). To complement the ELISA method, molecular diagnostics based on reversetranscription polymerase chain reaction (RT-PCR) were developed. For template preparation, a commercially available RNA extraction kit and an inexpensive total nucleic acid procedure were compared. IYSV-specific primers were designed and a highly sensitive and rapid real-time RTPCR assay was developed.

\section{MATERIALS AND METHODS}

Plant material. Numerous onion samples (>500) with symptoms indicative of IYSV infection were collected from various research and commercial bulb and seed onion fields in the Columbia Basin of Oregon and Washington State and several other states in the western United States during 2005 and 2006 (20). Asymptomatic plants from the same fields also were collected for testing. Uninfected, healthy onion plants grown in an insect-proof greenhouse were used as negative controls in ELISA and PCR.

Cloning and expression of the $N$ gene in $E$. coli and production of antiserum. A cDNA clone of the $N$ gene of IYSV isolate originally collected from Grant County, WA (20) was used in this study. The 722-bp fragment of the gene was subcloned into $\mathrm{pET} 22 \mathrm{~b}$ protein expression vector (Invitrogen, Carlsbad, CA). Following induction, the viral protein was purified from the induced bacterial cells and its purity tested by sodium dodecyl sulfate 
(SDS) polyacrylamide gel electrophoresis. This recombinant viral protein (100 $\mu \mathrm{g} / \mathrm{rabbit}$ ) was used as an immunogen to inject two rabbits intradermally. Four additional boosters were given at weekly intervals using the Incomplete Freund's Adjuvant. Blood was obtained 2 weeks after every booster and the serum was collected and stored at $4^{\circ} \mathrm{C}$.

Indirect ELISA. ELISA assays were conducted in polystyrene microtiter plates (Fisher Scientific, Pittsburgh). Tissue was ground in liquid nitrogen and carbonate buffer $\left(1.59 \mathrm{~g}\right.$ of $\mathrm{Na}_{2} \mathrm{CO}_{3}$ and $2.93 \mathrm{~g}$ of $\mathrm{NaHCO}_{3}$ per liter of water, $\mathrm{pH}$ adjusted to
9.6) was added at the ratio of 1:10 (wt/vol) and $100 \mu \mathrm{l}$ of the extract was loaded per well. Each sample was run in duplicate. The plate was incubated overnight at $4^{\circ} \mathrm{C}$, covered in a plastic wrap in a humid box. Between each step, the plate was washed three times with ELISA wash buffer $(0.8 \mathrm{~g}$ of $\mathrm{KH}_{2} \mathrm{PO}_{4}, 0.8 \mathrm{~g}$ of $\mathrm{KCl}, 4.6 \mathrm{~g}$ of $\mathrm{NaPO}_{4}$ dibasic, $32 \mathrm{~g}$ of $\mathrm{NaCl}$, and $2 \mathrm{ml}$ of Tween in 4 liters of deionized water), $\mathrm{pH}$ 7.3. Following washing, $100 \mu \mathrm{l}$ of the blocking agent, BLOTTO (5\% skim milk in ELISA wash buffer) was added to each well and the plate was incubated for $30 \mathrm{~min}$ at room temperature. Anti-IYSV serum was diluted
1:3200 in BLOTTO, $100 \mu \mathrm{l}$ of the diluted antiserum was added to each well, and the plate was incubated for $90 \mathrm{~min}$ at room temperature. Goat-anti-rabbit alkaline phosphatase conjugate (Sigma-Aldrich, St. Louis) was diluted 1:10,000 in BLOTTO, $100 \mu \mathrm{l}$ of this diluted conjugate was added to each well, and the plate was incubated for $90 \mathrm{~min}$ at room temperature. The plate was washed three times, followed by the addition of $100 \mu \mathrm{l}$ of substrate $(1 \mathrm{mg} / \mathrm{ml}$ of p-nitrophenyl phosphate; Sigma-Aldrich) prepared in substrate buffer $(97 \mathrm{ml}$ of diethanolamine in 1 liter of water, $\mathrm{pH}$ adjusted to 9.8 with concentrated $\mathrm{HCl}$ ). The

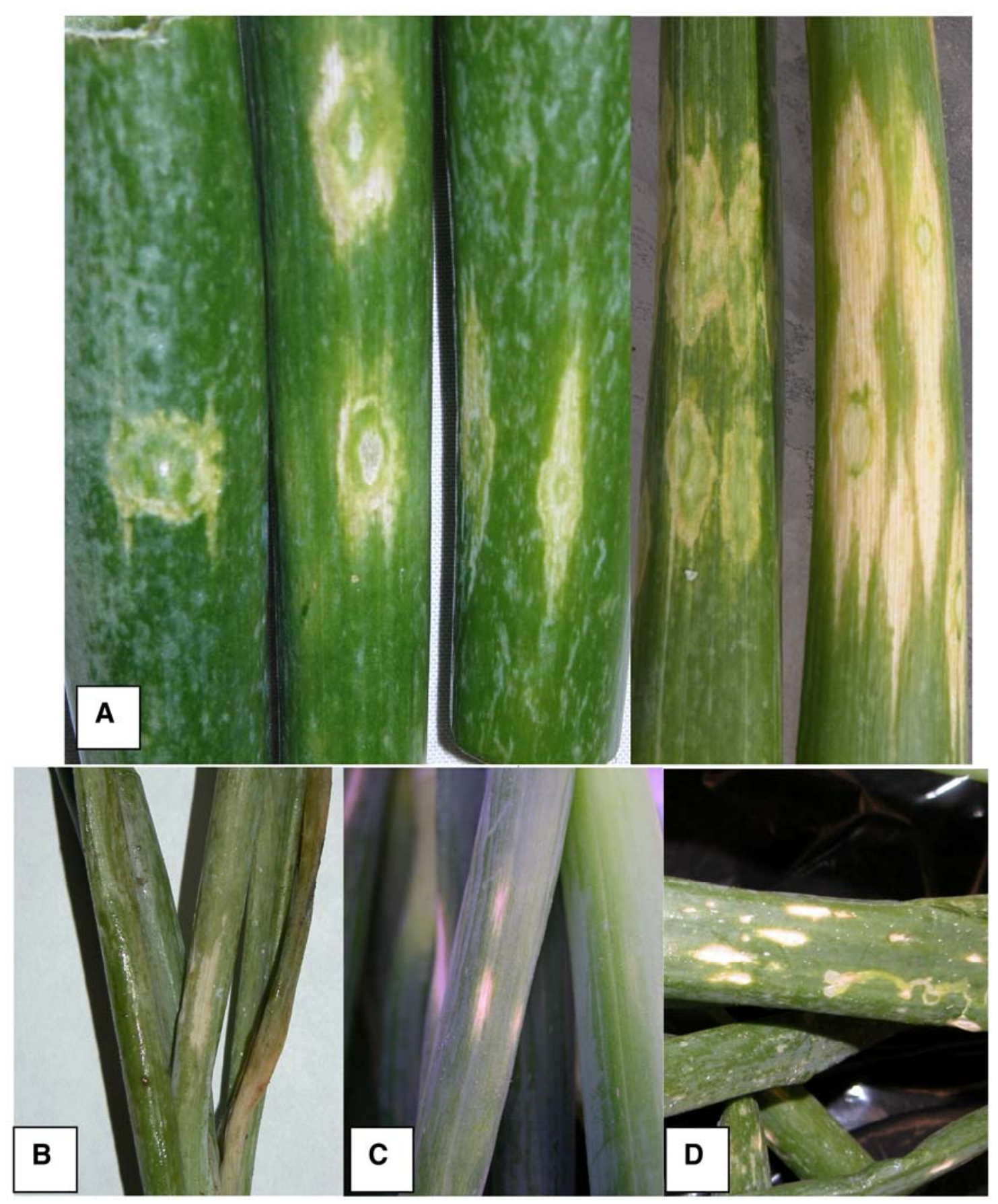

Fig. 1. Symptoms of Iris yellow spot virus (IYSV) infection of onion. A, Characteristic symptoms on scapes include diamond-shaped lesions with a green center surrounded by brownish halo. Progression of the lesions with time is shown from left to right. B-D, Less typical symptoms that also are associated with IYSV infection are seen on leaves. 
plate was incubated at room temperature for $2 \mathrm{~h}$ prior to recording the absorbance at $405 \mathrm{~nm}\left(\mathrm{~A}_{405}\right)$ values using a plate reader (Bio-Tek Instruments, Model Elx 800). ELISA was repeated at least three times on each plant sample tested. To test the limit of detection, serial, 10-fold dilutions of the sap were made in carbonate buffer. Tobacco plants individually infected with locally collected isolates of TSWV or Impatiens necrotic spot virus (INSV) and maintained in the greenhouse were used to test the IYSV-specific antiserum to determine potential cross-reactivity. Controls included IYSV-infected onion tissue, unin- fected onion tissue, and carbonate buffer. Absorbance values twice that of sap extract from uninfected onion leaves were considered positive for IYSV.

Template preparation for nucleic acid amplification. A commercially available kit and an in-house procedure based on a previously published protocol, referred to as modified Dellaporta method, were compared. For total nucleic acid extraction, the modified Dellaporta method (23) was used: Leaf sample (about $100 \mathrm{mg}$ ) was ground using mortar and pestle with $1 \mathrm{ml}$ of buffer $(100 \mathrm{mM}$ Tris, $\mathrm{pH} 8.0,50 \mathrm{mM}$ EDTA, $500 \mathrm{mM} \mathrm{NaCl}$, and $10 \mathrm{mM}$ mer- captoethanol). The extract was transferred to a $1.7-\mathrm{ml}$ microcentrifuge tube to which $140 \mu \mathrm{l}$ of $10 \%$ SDS was added. The sample was mixed by inversion and incubated at $65^{\circ} \mathrm{C}$ for $15 \mathrm{~min}$. Following the incubation, $250 \mu$ of $8 \mathrm{M}$ potassium acetate was added, mixed by inversion, and kept on ice for $20 \mathrm{~min}$. The sample then was centrifuged in a microcentrifuge at $15,000 \mathrm{rpm}$ for $10 \mathrm{~min}$. The supernatant was transferred to a fresh microcentrifuge tube containing $600 \mu \mathrm{l}$ of isopropanol. The sample was mixed by inversion and kept on ice for $10 \mathrm{~min}$, followed by centrifugation at $15,000 \mathrm{rpm}$ for $10 \mathrm{~min}$. The supernatant
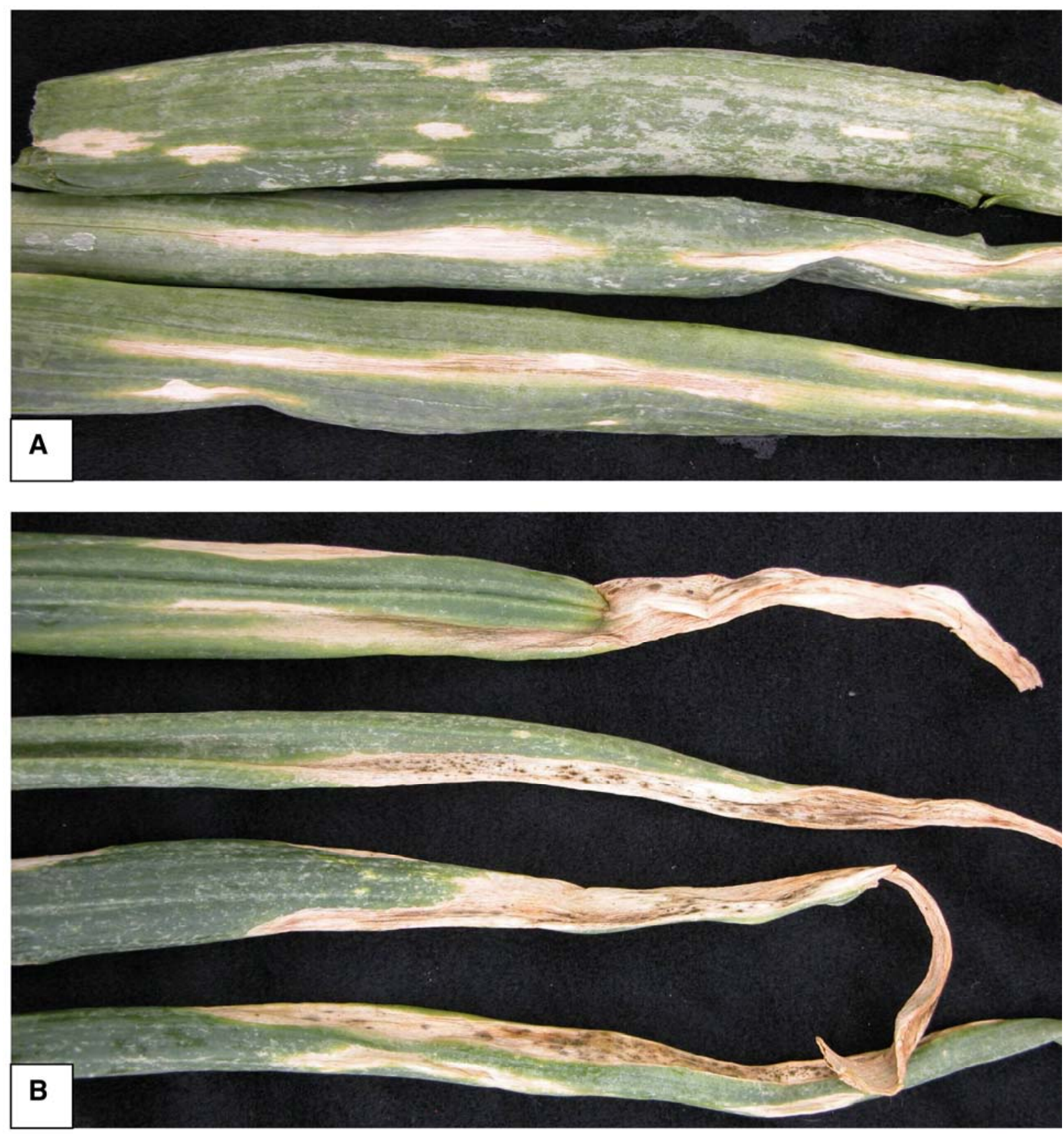

Fig. 2. Diversity of symptoms caused by Iris yellow spot virus (IYSV) on onion. A, Top leaf has one characteristic diamond-shaped lesion (to the left) and several lesions that are near-diamond shaped. Middle and bottom leaves show the result of individual lesions expanding and coalescing, leading to drying of the leaf. Damage due to thrips feeding also could be seen on the top leaf. B, Effect of disease progression on symptomatology of IYSV-infected onion. As the lesions expand and coalesce causing extensive drying of the leaves, secondary, saprophytic organisms such as Stemphylium, Cladosporium, or Alternaria spp. colonize the leaves (dark spots on the brownish lesions). 
was discarded and the pellet was washed with $500 \mu \mathrm{l}$ of $70 \%$ ethanol. The nucleic acid pellet was dried in SpeedVac and resuspended in $100 \mu \mathrm{l}$ of sterile distilled water. A 1:5 dilution of this preparation was used in PCR. Ten-fold dilutions of this preparation in healthy onion leaf sap were used to estimate the limit of detection. Total RNA extraction from plant tissue was made by using the RNeasy Plant Mini Kit (Qiagen, Valencia, CA). About $100 \mathrm{mg}$ of leaf material from the same leaf used above was processed by following the protocol given by the manufacturer. Final elution was done in $100 \mu \mathrm{l}$. Ten-fold dilutions of this preparation in healthy onion leaf extract were used to estimate the limit of detection. Each time, four leaf samples from individual plants were tested and the experiment was repeated at least three times.

Standard RT-PCR. First-strand cDNA was synthesized using $5 \mu \mathrm{l}$ of total RNA prepared by using the Qiagen's RNeasy kit, or total nucleic acid extract from plants prepared by using the modified Dellaporta method (23) and their respective serial dilutions. The M-MLV reverse transcriptase (Invitrogen) was used following the manufacturer's protocol. The reaction mixture had $0.25 \mu \mathrm{M}$ of the primer IYSV465c (5' CAGCAAAGTGAGAGGACCACC $3^{\prime}$ ), and $0.5 \mathrm{mM}$ of each of the four dNTPs in a final volume of $20 \mu \mathrm{l}$. First-strand cDNA synthesis was carried out at $42^{\circ} \mathrm{C}$ for $45 \mathrm{~min}$. The product of this reaction $(1 \mu \mathrm{l})$ was used in PCR (Icycler; Bio-Rad Laboratories, Hercules, CA). The PCR reagent mix included $20 \mathrm{mM}$ Tris$\mathrm{HCl}(\mathrm{pH} 8.4), 50 \mathrm{mM} \mathrm{KCl}, 1.5 \mathrm{mM}$ $\mathrm{MgCl}_{2}, 0.625 \mathrm{mM}$ each of the four dNTPs, $0.25 \mu \mathrm{M}$ each primer (IYSV-465c: 5' AGCAAAGTGAGAGGACCACC $3^{\prime}$ and IYSV-239f: 5' TGAGCCCCAATCAAGACG 3'), and $1 \mathrm{U}$ of Taq DNA Polymerase (5 U/ $\mu \mathrm{l}$; Invitrogen). The PCR profile consisted of 40 cycles, each one consisting of $94^{\circ} \mathrm{C}$ for $30 \mathrm{~s}, 60^{\circ} \mathrm{C}$ for $30 \mathrm{~s}$, and $72^{\circ} \mathrm{C}$ for $20 \mathrm{~s}$. A final extension of $72^{\circ} \mathrm{C}$ for 5 min was added at the end of the 40 cycles. PCR products were analyzed by agarose gel electrophoresis (26).

Real-time RT-PCR. Primers for real time RT-PCR. Using sequences of the IYSV $N$ gene available in GenBank, a set of specific primers was designed using the Vector NTI (version 9.0.0). The primer pair consisted of IYSV-465c (5' CAGCAA AGTGAGAGGACCACC $3^{\prime}$ ) and IYSV239f (5' TGAGCCCCAATCAAGACG 3') to amplify a 227-bp fragment of the $N$ gene. The real-time PCR, in a total volume of $25 \mu \mathrm{l}$, contained $1 \mu \mathrm{l}$ of the first-strand cDNA, $0.1 \mu \mathrm{M}$ each of the primers (IYSV $465 \mathrm{c}$ and IYSV 239f), $12.5 \mu \mathrm{l}$ of IQ SYBR Green Supermix (Bio-Rad Laboratories), and $10.5 \mu \mathrm{l}$ of sterile distilled water. The PCR was initiated with a denaturation at $95^{\circ} \mathrm{C}$ for $3 \mathrm{~min}$, followed by 35 cycles of denaturation at $94^{\circ} \mathrm{C}$ for $30 \mathrm{~s}$, annealing at $60^{\circ} \mathrm{C}$ for $20 \mathrm{~s}$, and extension at $72^{\circ} \mathrm{C}$ for $20 \mathrm{~s}$ using ICycler (Bio-Rad Laboratories).

Table 1. Indirect format of enzyme-linked immunosorbent assay for the detection of Iris yellow spot virus infection of onion ${ }^{\mathrm{a}}$

\begin{tabular}{lccccccc}
\hline Dilution $^{b}$ & Uninfected $^{c}$ & California & Colorado & Idaho & New York & Oregon & Washington \\
\hline $1: 10$ & 0.11 & 2.2 & 2.1 & 1.9 & 2.6 & 2.3 & 2.1 \\
$1: 100$ & 0.08 & 1.2 & 1.15 & 1.1 & 1.56 & 1.55 & 1.24 \\
$1: 1000$ & 0.11 & 0.45 & 0.39 & 0.49 & 0.56 & 0.52 & 0.54 \\
$1: 10000$ & 0.1 & 0.21 & 0.23 & 0.18 & 0.28 & 0.27 & 0.21 \\
\hline
\end{tabular}

a Samples from several states were tested. Absorbance at $405 \mathrm{~nm}$ values are shown; values are the average of three experiments.

b Dilution of the infected tissue extract.

c Healthy control.
Data collection was enabled after each extension step. Immediately after the final PCR cycle, a melting curve analysis was done to determine the specificity of the reaction by incubating the reaction at $95^{\circ} \mathrm{C}$ for $1 \mathrm{~min}$, annealing at $60^{\circ} \mathrm{C}$ for $1 \mathrm{~min}$, and then increasing the temperature by $0.5^{\circ} \mathrm{C}$ per minute for $10 \mathrm{~min}$. At the end of the PCR, all reactions were analyzed by agarose gel electrophoresis (26).

\section{RESULTS}

Symptomatology of IYSV in onion. IYSV infection often results in diamondshaped lesions on scapes that are of diagnostic value (Fig. 1A). However, lesscharacteristic symptoms such as circular or oval yellow spots also are associated with IYSV infection (Fig. 1B-D) and, depending on the time of sampling, lesions coalesce, leading to drying of the affected leaves (Fig. 2A). These dead parts of the leaves often are colonized by secondary invaders such as Alternaria spp. or Stemphylium spp., which could lead to misdiagnosis (Fig. 2B).

Detection of IYSV by ELISA. The antiserum produced in rabbits was evaluated for its specificity and sensitivity of detection and the ability to detect a wide range of isolates collected from the region, and the results are summarized in Table 1 . The antiserum was found to be specific to IYSV because it did not react with uninfected onion tissue extracts (Table 1). IYSV could be detected in up to $1: 1000$ dilution of IYSV-infected onion tissue extracts of samples collected from several states in the United States (Table 1). No cross reactivity was seen with INSV and TSWV. The $\mathrm{A}_{405}$ values for TSWV, INSV, and buffer controls were $0.09,0.1$, and 0.09 , respectively.

Detection of IYSV by standard RTPCR. The primers were able to amplify the amplicon of expected size and little or no nonspecific amplification could be seen. Uninfected, negative controls did not produce any amplicons. Both procedures

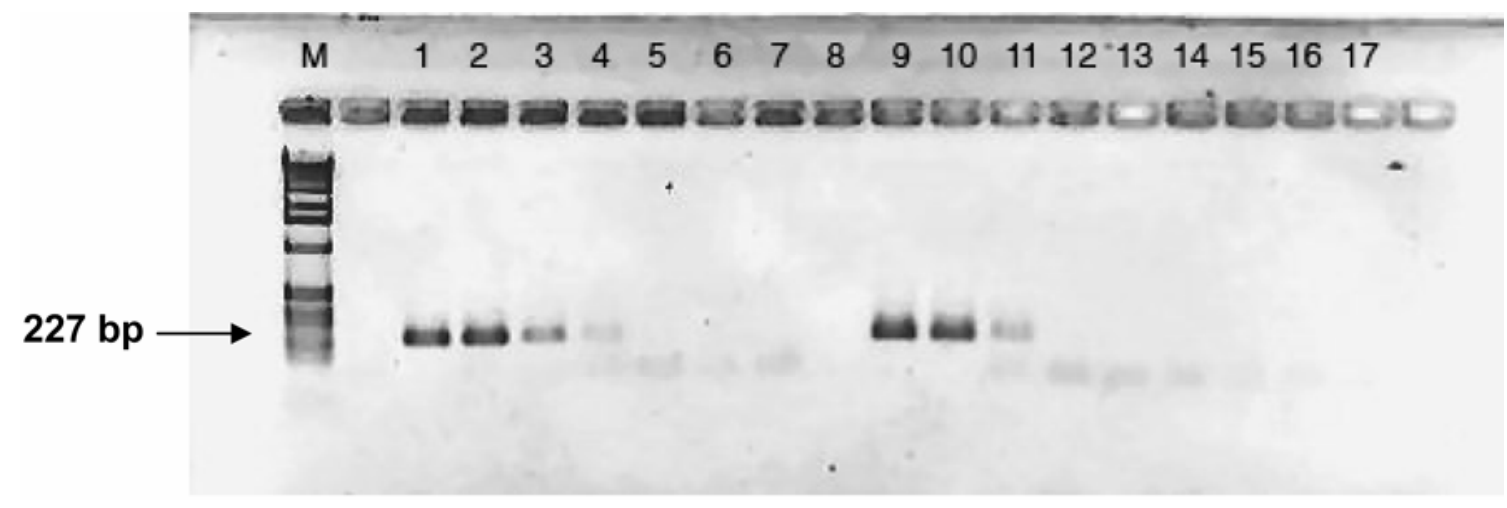

Fig. 3. Molecular detection of Iris yellow spot virus. Agarose gel electrophoresis of reaction products of reverse-transcription polymerase chain reaction (RTPCR). M, $1 \mathrm{~kb}$ ladder. Lanes 1 to 7: RT-PCR products obtained from total plant RNA prepared by RNeasy kit. Lane 1, nondiluted or lane 2 diluted 1:10; lane 3, 1:100; lane 4, 1:1000; lane 5, 1:10000; lane 6, 1:100000; and lane 7, 1:1000000. Lane 8, healthy control. Lanes 9 to 15, RT-PCR products obtained from total nucleic acid prepared by modified Dellaporta method. Lane 9, nondiluted or lane 10, diluted 1:10; lane 11, 1:100; lane 12, 1:1000; lane 13, 1:10000; lane 14, 1:100000; and lane 15, 1:1000000. Lane 16, healthy control; lane 17, water control. The expected amplicon was indicated by an arrow. 
Table 2. A real-time reverse-transcription polymerase chain reaction (RT-PCR) test for the detection of Iris yellow spot virus (IYSV)

\begin{tabular}{lccc}
\hline & & \multicolumn{2}{c}{ Ct value $^{\mathbf{a}}$} \\
\cline { 3 - 4 } Sample $^{\mathbf{b}}$ & Dilution & Dellaporta $^{\mathbf{c}}$ & RNeasy $^{\mathbf{d}}$ \\
\hline Infected plant & 1 & 16.1 & 15.0 \\
Infected plant & $1: 10$ & 17.9 & 17.8 \\
Infected plant & $1: 10^{2}$ & 22.3 & 20.7 \\
Infected plant & $1: 10^{3}$ & 26.0 & 25.3 \\
Infected plant & $1: 10^{4}$ & 28.6 & 28.0 \\
Infected plant & $1: 10^{5}$ & 28.7 & 28.7 \\
Infected plant & $1: 10^{6}$ & 30.6 & 31.7 \\
Uninfected plant & 1 & 29.5 & 29.5 \\
Water control & $\mathrm{n} / \mathrm{a}^{\mathrm{e}}$ & 33.6 & 33.6 \\
\hline
\end{tabular}

${ }^{a} \mathrm{Ct}$ refers to comparative threshold cycle, which is the cycle number during PCR when the fluorescence from the newly synthesized DNA amplicon exceeds the background amplification.

b Total plant RNA or nucleic acid was extracted from infected and uninfected plants and was used in RT-PCR. Primers used were IYSV 465c and IYSV 239f. A 10-fold dilution series of the nucleic acid from infected plant was used to determine the sensitivity of the test.

${ }^{\mathrm{c}}$ Template was prepared by using a modified Dellaporta method (26) as described in Materials and Methods.

d Template was prepared by using the RNeasy Kit (Qiagen).

${ }^{\mathrm{e}}$ Not applicable. that were used for preparing the template for RT-PCR were effective in providing unambiguous PCR results (Fig. 3). The limits of detection for end-point dilutions were $10^{-2}$ and $10^{-3}$ for the modified Dellaporta method and the commercial kit, respectively (Fig. 3). The PCR product resulting from each extraction procedure was cloned and sequenced to verify the identity of the amplicon as IYSV (20).

Detection of IYSV by real-time RTPCR. The two methods of extraction were compared to evaluate the quality of the template for use in real-time RT-PCR. Based on the threshold cycle values of diluted extracts, no difference in the limit of detection could be seen between template preparations made by using the RNeasy Kit or the modified Dellaporta method (Table 2). The amplification was IYSV specific based on the melting curves and agarose gel electrophoresis of the PCR reactions (not shown). Using diluted ex-

A

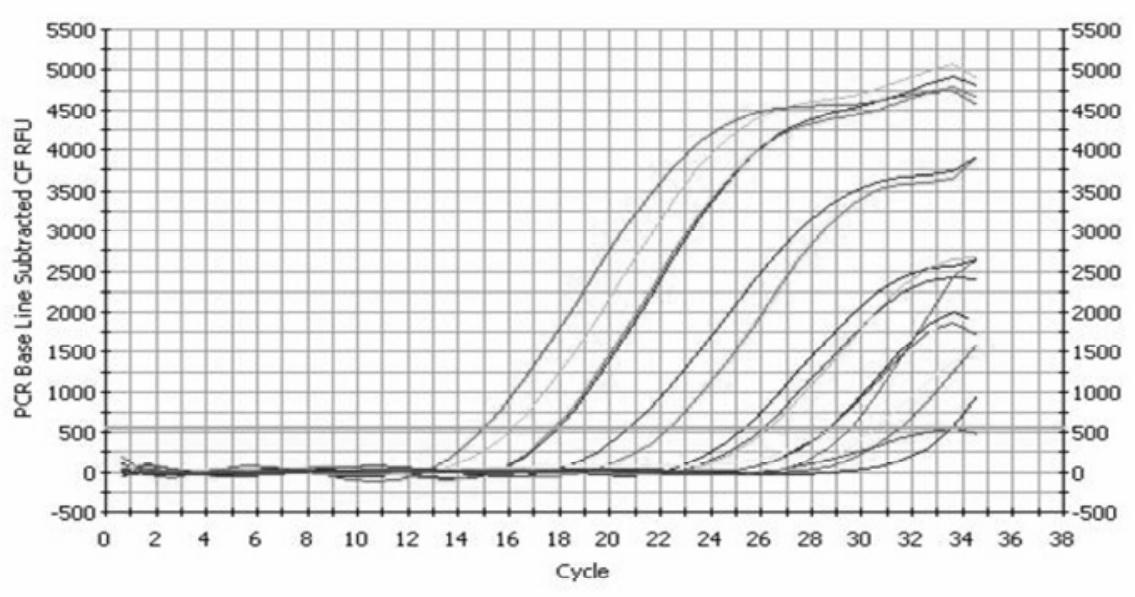

B

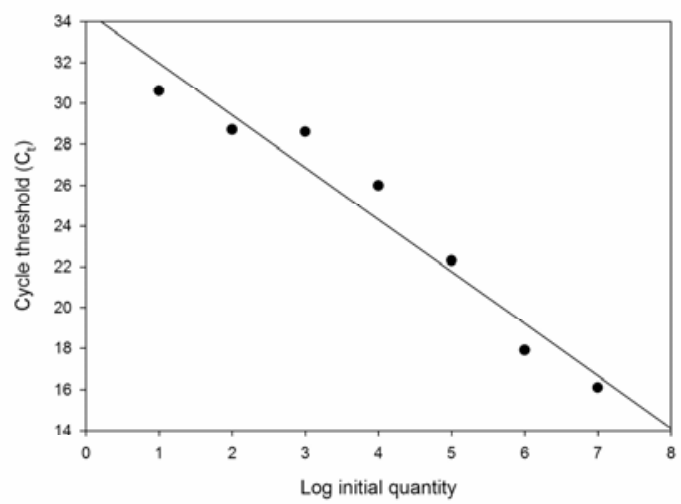

$\begin{aligned} y & =-2.55 x+16.6 \\ R^{2} & =0.945\end{aligned}$
Standard Curve using SYBR green (Qiagen method)

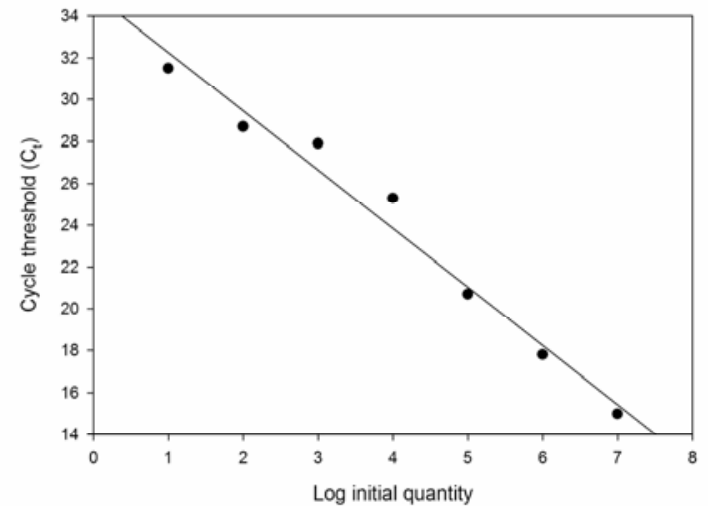

\section{$y=-2.8 x+15.44$ \\ $R^{2}=0.975$}

Fig. 4. Real-time polymerase chain reaction (PCR) assay for Iris yellow spot virus (IYSV) detection. A, Kinetics of amplification. Ten-fold dilution series of the nucleic acid from IYSV-infected plants were reverse transcribed and used as a template to amplify 227-bp fragment of the IYSV nucleocapsid gene by SYBR Green real-time PCR. The data values are shown in Table 2. Fluorescence observed above the base line is the result of specific amplification of viral genome from infected plant. IYSV could be detected in up to 1:100000 dilution of plant sap. B, Linear relationship between cycle threshold values and the dilutions of template. Fluorescence observed above the base line is the result of specific amplification of viral genome from infected plant. IYSV could be detected in up to 1:100000 dilution of plant sap. 
tracts, IYSV could be detected in $1: 10^{-6}$ in real-time RT-PCR (Fig. 4; Table 2).

\section{DISCUSSION}

IYSV is becoming an increasingly important constraint to onion production in the United States and several parts of the world (7). Rapid and accurate diagnostic tools and methods are essential to better understand the epidemiology of the virus and to devise effective management strategies. The distribution of IYSV within an infected plant is uneven $(27,28)$. Using bacterially expressed $\mathrm{N}$ protein of IYSV, we produced and characterized IYSVspecific antiserum and an indirect ELISA was developed for IYSV detection. It has been difficult to propagate IYSV because mechanical transmission to other hosts is not very efficient. As a result, it is difficult to obtain purified virus in sufficient quantities for producing antisera. Expression of the cloned viral genes in bacteria and their subsequent purification and use for immunization offer an advantage in such situations. Compared with a double-antibody sandwich ELISA, in which the virusspecific antibody has to be chemically modified to produce the conjugated antibody, indirect ELISA has an advantage in that the secondary conjugated antibody is commercially available. IYSV has been the predominant tospovirus associated with onion crops in the United States with the exception of onion crops in Georgia, where co-infection with TSWV was reported (17). In such cases, samples may need to be tested for both IYSV and TSWV.

To complement the ELISA procedures for IYSV detection, IYSV-specific primers were designed and used in standard and real-time RT-PCR methods. In situations where the absorbance values turned out to be "border line" compared with healthy controls, RT-PCR may be used to verify the result. Additionally, to confirm the incidence of IYSV in a new area, verification of ELISA-positive samples by an RTPCR followed by sequence determination provides unequivocal evidence of the presence of the virus. A commercially available kit for template preparation and a procedure that uses commonly available chemicals were compared. Compared with the commercially available kit, the "in-house" procedure provided quality template suitable for both standard RT-PCR and realtime RT-PCR. Our results showed that there was a 10 -fold difference in detection sensitivity between the template preparation procedures. However, where such kits are not available or difficult to obtain, the total nucleic acid extraction procedure could be used because this method provided templates from onion leaf tissue that are suitable for use in RT-PCR. We did not attempt to quantify the relative efficiency of extraction of the total RNA templates for these two methods, because the two extraction procedures give different tem- plates for the assay. The commercial kit provides total plant RNA while the modified Dellaporta method yields total plant nucleic acids.

The primers were highly specific and the primer sequences were highly conserved in over 20 isolates sequenced $(7,20)$ and should be useful for broad-spectrum detection of IYSV isolates. Real-time RTPCR was more sensitive than standard RTPCR. Real-time RT-PCR assay allows sensitive, rapid, and high-throughput IYSV detection and is of value in determining the titer of the viral RNA in time-course studies or where the viral RNA quantification needs to be determined for assessing the relative levels of resistance or tolerance in germplasm or breeding lines. With appropriate positive and negative controls, interpretation of the data is relatively simple. However, detection of amplicons by real-time PCR requires expensive and more sophisticated equipment when compared with standard RT-PCR. The capital expenditure required for conducting realtime PCR is worthwhile where superior sensitivity and rapidity are needed. Standard RT-PCR and real-time RT-PCR can be adapted to testing multiple samples in a short period of time because neither template preparation procedure is time consuming. The diagnostic tools and methodologies for ELISA and RT-PCR techniques should aid in more accurate and improved diagnosis of IYSV infection.

\section{ACKNOWLEDGMENTS}

Research was supported in part by grants from USDA-CSREES Critical and Emerging Pests and Diseases Grants Program, Columbia Basin Vegetable Seed Association, Pacific Northwest Vegetable Association, and Washington State Commission for Pesticide Registration, PPNS No. 0481, Department of Plant Pathology, College of Agricultural, Human and Natural Resource Sciences, Agricultural Research Center, Project no. WNP0 0545, Washington State University, Pullman. I. M. Rosales's visit to Washington State University was supported by a grant from CONICYT-Chile, "Pasantías de formación tecnológica para organismos del sector público."

\section{LITERATURE CITED}

1. Abad, J. A., Speck, J., Mohan, S. K., and Moyer, J. W. 2003. Diversity of the Iris yellow spot virus $\mathrm{N}$ gene in the USA. (Abstr.) Phytopathology 93:S1.

2. Cortês, I., Livieratos, I. C., Derks, A., Peters, D., and Kormelink, R. 1998. Molecular and serological characterization of Iris yellow spot virus, a new and distinct tospovirus species. Phytopathology 88:1276-1282.

3. Culbreath, A. K., Todd, J. W., and Brown, S. L. 2005. Epidemiology and management of tomato spotted wilt in peanut. Annu. Rev. Phytopathol. 41:53-75.

4. du Toit, L. J., and Pelter, G. Q. 2005. Susceptibility of storage onion cultivars to iris yellow spot in the Columbia Basin of Washington, 2004. Biol. Cult. Tests 20:V006.

5. du Toit, L. J., Pelter, G. Q., and Pappu, H. R. 2003. Iris yellow spot virus. APSnet Image of the Week. http://apsnet.org/online/archive/ 2003/IW000030.asp

6. du Toit, L. J., Pelter, G. Q., and Pappu, H. R. 2004. IYSV challenges to the onion seed industry in Washington. Pages 103, 213-217 in:
Proc. Natl. Allium Res. Conf. Grand Junction, CO. Colorado State University, Fort Collins.

7. Gent, D., du Toit, L. J., Fichtner, S. F., Krishna Mohan, S., Pappu, H. R., and Schwartz, H. F. 2006. Iris yellow spot virus: an emerging threat to onion bulb and seed production. Plant Dis. 90:1468-1480.

8. Gent, D. H., Schwartz, H. F., and Khosla, R. 2004. Distribution and incidence of Iris yellow spot virus and its relation to onion plant population and yield. Plant Dis. 88:446-452.

9. Hall, J. M., Mohan, K., Knott, E. A., and Moyer, J. W. 1993. Tospoviruses associated with scape blight of onion (Allium cepa) seed crops in Idaho. Plant Dis. 77:952.

10. Hellier, B., Pappu, H. R., and Dugan, F. 2005. Symptoms of Iris yellow spot virus on wild onion. APSnet Image of the Week. http://apsnet. org/online/archive/2004/iw000049.asp

11. Hoepting, C. A., Schwartz, H. F., and Pappu, H. R. 2007. First report of Iris yellow spot virus in New York. Plant Dis. 91:327.

12. Huchette, O., Filomenko, R., Pouleau, B. Godbert, N., Larièpe, A., Out, H., and Seddas, S. 2006. Development of an easy and reliable method to diagnose the Iris yellow spot virus in Burgundy, France. Proc. Natl. Allium Res. Conf. College Station, TX.

13. Kritzman, A., Lampel, M., Raccah, B., and Gera, A. 2001. Distribution and transmission of Iris yellow spot virus. Plant Dis. 85:838-842.

14. Mohan, S. K., and Moyer, J. W. 2004. Iris yellow spot virus in onion seed and bulb crops. (Abstr.) Phytopathology 94:S153.

15. Moyer, J. W. 1999. Tospoviruses (Bunyaviridae). Pages 1803-1807 in: Encyclopedia of Virology. A. Granoff and R. G. Webster, eds. Academic Press, San Diego, CA.

16. Moyer, J. W., Abad, J. A., Ullman, D., and Mohan, K. 2003. INSV and IYSV; the other tospoviruses in the United States. (Abstr.) Phytopathology 93:S115.

17. Mullis, S. W., Langston Jr., D. B., Gitaitis, R. D., Sherwood, J. L., and Csinos, A. C. 2004 First report of Vidalia onion (Allium cepa) naturally infected with Tomato spotted wilt virus and Iris yellow spot virus (family Bunyaviridae, genus Tospovirus) in Georgia. Plant Dis. 88:1285.

18. Nagata, T., Almeida, A. C. L., Resende, R. de O., and de Avila, A. C. 1999. The identification of the vector species of Iris yellow spot tospovirus occurring on onion in Brazil. Plant Dis. 83:399.

19. Nischwitz, C., Mullis, S. W., Csinos, A. S., Langston, D. B., Sparks, A. N., Torrance, R. L., Rafael Mallaupoma, Z. C., Inguil Rojas, E. H., and Gitaitis, R. D. 2006. Phylogenetic analysis of the $\mathrm{N}$ gene links Georgia strains of Iris yellow spot virus to strains from Peru. (Abstr.) Phytopathology 96:S84

20. Pappu, H. R., du Toit, L. J., Schwartz, H. F, and Mohan, S. K. 2006. Sequence diversity of the nucleoprotein gene of Iris yellow spot virus (genus Tospovirus, family Bunyaviridae) isolates from the western region of the United States. Arch. Virol. 151:1015-1023.

21. Pappu, H. R., Sampangi, R., and Krishna Mohan, S. 2006. Symptoms of Iris yellow spot virus on onion. APSnet Image of the Week. http://apsnet.org/online/Archive/2006/IW0000 75.asp

22. Poole, G. J., Pappu, H. R., Davis, R. M., and Turini, T. A. 2006. Increasing incidence and impact of Iris yellow spot virus in bulb and seed onion crops in Imperial and Antelope valleys of California. Plant Health Progress. doi:10.1094/PHP-2007-0508-01-BR.

23. Presting, G. G., Smith, O. P., and Brown, C. R. 1995. Resistance to potato leaf roll virus in potato plants transformed with the coat protein gene or with vector control constructs. Phytopathology 85:436-442.

24. Riley, D. G., and Pappu, H. R. 2000. Evalua- 
tion of tactics for management of thrips vectored Tomato spotted wilt tospovirus in tomato. Plant Dis. 84:847-852.

25. Riley, D. G., and Pappu, H. R. 2004. Tactics for Management of thrips (Thysanoptera: Thripidae) and Tomato spotted wilt virus in tomato. J. Econ. Entomol. 97:1648-1658.

26. Sambrook, J., and Russell, D. W. 2001. In: Molecular Cloning: A Laboratory Manual, 3rd ed. Cold Spring Harbor Laboratory Press, Cold Spring Harbor, NY.

27. Schwartz, H. F., and du Toit, L. J. 2006. Integrated management of Iris yellow spot virus in onion bulb and seed crops. (Abstr.) Proc. Natl. Allium Res. Conf. College Station, TX.

28. Smith, T. N., Wylie, S. J., Coutts, B. A., and Jones, R. A. C. 2006. Localized distribution of Iris yellow spot virus within leeks and its reli- able large-scale detection. Plant Dis. 90:729733.

29. Ullman, D. E., Meideros, R., Campbell, L. R., Whitfield, A. E., Sherwood, J. L., and German, T. L. 2002. Thrips as vectors of tospoviruses. Adv. Bot. Res. 36:113-140.

30. Whitfield, A. E., Ullman, D. E., and German, T. L. 2005. Tospovirus-thrips interactions. Annu. Rev. Phytopathol. 43:459-489. 